University of Nebraska - Lincoln

DigitalCommons@University of Nebraska - Lincoln

$12-13-2018$

\title{
The influence of depth and velocity on age-0 Scaphirhynchus sturgeon prey consumption: Implications for aquatic habitat restoration
}

T R. Gemeinhardt

Nathan J.C. Gosch

Anthony P. Civiello

Nathan J. Chrisman

Heather H. Shaughnessy

See next page for additional authors

Follow this and additional works at: https://digitalcommons.unl.edu/usarmyceomaha

This Article is brought to you for free and open access by the U.S. Department of Defense at

DigitalCommons@University of Nebraska - Lincoln. It has been accepted for inclusion in US Army Corps of Engineers by an authorized administrator of DigitalCommons@University of Nebraska - Lincoln. 


\section{Authors}

T R. Gemeinhardt, Nathan J.C. Gosch, Anthony P. Civiello, Nathan J. Chrisman, Heather H. Shaughnessy, Tracy L. Brown, James M. Long, and Joseph L. Bonneau 


\title{
The influence of depth and velocity on age- 0 Scaphirhynchus sturgeon prey consumption: Implications for aquatic habitat restoration
}

\author{
Todd R. Gemeinhardt ${ }^{1}$ (D) | Nathan J.C. Gosch ${ }^{1}$ (D) | Anthony P. Civiello ${ }^{1}$ (D) । \\ Nathan J. Chrisman ${ }^{2}$ | Heather H. Shaughnessy ${ }^{2}$ | Tracy L. Brown ${ }^{3}$ | James M. Long ${ }^{4}$ (i) । \\ Joseph L. Bonneau ${ }^{5}$
}

${ }^{1}$ Environmental Resources Section, U.S. Army Corps of Engineers, Kansas City, Missouri, United States

${ }^{2}$ River Engineering and Restoration Section, U.S. Army Corps of Engineers, Kansas City, Missouri, United States

${ }^{3}$ Geospatial Branch, U.S. Army Corps of Engineers, Kansas City, Missouri, United States

${ }^{4}$ U.S. Geological Survey, Oklahoma Cooperative Fish and Wildlife Research Unit, Department of Natural Resources Ecology and Management, Oklahoma State University, Stillwater, Oklahoma, United States

${ }^{5}$ Integrated Science Program, U.S. Army Corps of Engineers, Yankton, South Dakota, United States

Correspondence

Todd R. Gemeinhardt, U.S. Army Corps of Engineers, Environmental Resources Section, Kansas City, MO 64106.

Email: todd.r.gemeinhardt@usace.army.mil

Funding information

Funding was provided by the USACE, Kansas City and Omaha Districts and U.S. Geological Survey Cooperative Agreements G14AS0004 and G15AC00323

\begin{abstract}
After the pallid sturgeon (Scaphirhynchus albus) was listed as endangered in 1990, a variety of management actions focusing on early life history needs have been implemented to aid species recovery. Given the scarcity of age-0 pallid sturgeon, managers and scientists have relied on sympatric congeners to evaluate the effectiveness of management actions in the short term; however, increased understanding of habitat requirements for age-0 Scaphirhynchus sturgeon is still needed to appropriately focus management efforts. Recently, a lack of food-producing and foraging habitats were proposed as potential limiting factors for pallid sturgeon, and the purpose of this study was to evaluate the current definition of these habitats at multiple spatial scales using data from age-0 Scaphirhynchus sturgeon (shovelnose sturgeon [Scaphirhynchus platyrhynchus] or hybrid [shovelnose sturgeon $\mathrm{x}$ pallid sturgeon]). Results showed the water depths and velocities that currently define age- 0 pallid sturgeon foraging habitat had little effect on age-0 Scaphirhynchus sturgeon prey consumption. Similar results occurred when evaluating the relationship between prey consumption and food-producing habitat present 10 , 20 , and 30 days before capture. Assuming that individuals captured during this study were a valid surrogate, these results suggest that increasing foraging and food-producing habitat as defined by the current depth and velocity criteria is unlikely to result in the desired benefits of increased growth and survival of age- 0 pallid sturgeon.
\end{abstract}

\section{KEYWORDS}

adaptive management, foraging, habitat restoration, Scaphirhynchus sturgeon

\section{1 | INTRODUCTION}

After the pallid sturgeon Scaphirhynchus albus was listed as endangered in 1990, a variety of management actions have been implemented to aid species recovery. On the lower Missouri River (LMOR; Gavins Point Dam, South Dakota downstream to the Mississippi River confluence at
St. Louis, Missouri), aquatic habitat restoration has focused on increasing survival of age- 0 pallid sturgeon to spur population growth (U.S. Fish and Wildlife Service (USFWS), 2000, 2003). From 2003 to 2015, restoration activities involved increasing shallow-water habitat, areas defined as depth $<1.5 \mathrm{~m}$ and velocity $<0.61 \mathrm{~m} / \mathrm{s}$ at median August flow (USFWS, $2000,2003)$. This definition included specific features such as side 
channels, backwaters, depositional sandbars detached from the bank, and low-lying depositional areas adjacent to shorelines (Olson, 2009).

Management of endangered species, however, often requires decision-making with incomplete knowledge and insufficient time to evaluate hypotheses prior to implementing actions (Runge, 2011), and management of pallid sturgeon in the Missouri River is certainly no exception. Given the similarities in development (Colombo, Garvey, \& Wills, 2007) and rarity of age-0 pallid sturgeon, managers and scientists have relied on sympatric congeners to evaluate the effectiveness of management actions in the short term. Recent studies of post-drift, age-0 Scaphirhynchus sturgeon suggest shallow-water habitat restoration, as defined, may not provide the hypothesized benefits of increased survivorship and subsequent population growth (Civiello et al., 2018; Gemeinhardt et al., 2016; Gosch et al., 2017). These types of uncertainties demonstrate the need for an adaptive management approach to Missouri River management (Doyle et al., 2011; NRC, 2011). Prior to the development of an adaptive management plan, however, Doyle et al. (2011) recommended that an effects analysis, as described by Murphy and Weiland (2011), should be undertaken. The focus of the effects analysis was to describe how Missouri River management has affected and may affect pallid sturgeon. This analysis utilized all available scientific information and culminated with a number of hypotheses regarding the effects of current Missouri River management on pallid sturgeon and potential management actions to benefit pallid sturgeon (Jacobson et al. 2016). Following the Jacobson et al. (2016) effects analysis, the U.S. Army Corps and Engineers (USACE), the USFWS, and the Missouri River Recovery Implementation Committee (stakeholder group) developed a Science and Adaptive Management Plan to guide implementation and evaluation of pallid sturgeon management actions on the Missouri River (Fischenich et al., 2017).

These documents (Fischenich et al., 2017; Jacobson et al., 2016) included alternative age- 0 pallid sturgeon habitat criteria to guide habitat restoration projects. Jacobson et al. (2016) posited three necessary functional elements of age- 0 pallid sturgeon habitat: interception defined as the process by which drifting free embryos are transferred from the thalweg into supportive channel margin areas; food-producing habitat defined as areas with velocities $<0.08 \mathrm{~m} / \mathrm{s}$ (areas that produce benthic invertebrates consumed by age- 0 Scaphirhynchus sturgeon); and foraging habitat defined as water with depths of 1-3 m and velocities between 0.5 and $0.7 \mathrm{~m} / \mathrm{s}$ (areas where young Scaphirhynchus sturgeon feed; Jacobson et al., 2016). These elements provide a hypothesized description of habitat components used by age- 0 pallid sturgeon and are currently being used to aid in the design of habitat projects on the LMOR with an initial annual restoration target of 33000 acre days over the next 6 years and an increase to 66,000 acre days in the subsequent 9 years (USFWS, 2018).

The age- 0 pallid sturgeon habitat definitions, however, were described as preliminary with a likely need for future adjustments as more information becomes available. For example, the proposed foraging habitat definition provided by Jacobson et al. (2016) relied solely on the depths and velocities measured within habitat types yielding the highest age-0 Scaphirhynchus sturgeon catch rates during 2007-2009 (Ridenour, Doyle, \& Hill, 2011) without any associated diet or prey availability data that would directly link habitat to foraging success. Additionally, more recent studies (Gemeinhardt et al., 2016; Gosch et al., 2017; Gosch, Miller, Gemeinhardt, Sampson, \& Bonneau, 2015; Hall et al., 2016) suggest that age-0 Scaphirhynchus sturgeon often use a wider range of depth and velocity compared with those reported by Ridenour et al. (2011).

Recent studies have also evaluated diet composition of age-0 Scaphirhynchus sturgeon (Braaten, Fuller, \& McClenning, 2007; Civiello et al., 2018; Gosch et al., 2016; Harrison, Slack, \& Killgore, 2014; Sechler et al., 2013; Sechler, Phelps, Tripp, \& Garvey, 2012), and Gosch, Civiello, Gemeinhardt, Bonneau, and Long (2018) found that age-0 pallid and shovelnose sturgeon (Scaphirhynchus platyrhynchus) consumed similar prey items; however, relationships between prey consumption and habitat, such as depth and velocity, were not investigated. Furthermore, past research has focused on the depths and velocities at, or very near, the point of capture rather than quantifying habitats available to age-0 Scaphirhynchus sturgeon at a variety of spatial scales. Therefore, the objective of this study was to utilize previously collected age-0 Scaphirhynchus sturgeon diet data (Civiello et al., 2018) to determine if fish captured from locations meeting the a priori proposed foraging and food-producing habitats exhibit increased prey consumption at multiple spatial scales. Understanding these relationships may provide the necessary information to guide future restoration measures, adjust monitoring metrics for habitat restoration projects, and contribute to an ongoing adaptive management strategy with the objective of increasing pallid sturgeon recruitment to age one.

\section{2 | METHODS}

\subsection{Fish collection and prey consumption}

Age-0 Scaphirhynchus sturgeon were collected monthly, May-October, during 2014 and 2015 from five reaches (26-37 km in length) of the LMOR (Figure 1; see Gosch et al., 2017), and a subset of these individuals was selected for diet analysis (Civiello et al., 2018). When water levels were too high for field crews to confidently locate dike structures, safety concerns precluded sampling. Reaches were chosen to represent a broad range (1.5-8.8 ha/ $\mathrm{km}$ ) of "shallow water habitat" relative to the past restoration target of 5.0-7.6 ha/ $\mathrm{km}$ (Gosch et al., 2017) but also included a wide range of the recently defined pallid sturgeon food-producing and foraging habitats. Fish tissue samples were sent to Dr. Edward Heist (Southern Illinois University), and genetic identification (Eichelberger, Braaten, Fuller, Krampe, \& Heist, 2014; Schrey, Sloss, Sheehan, Heidinger, \& Heist, 2007) found that none of the individuals used during this study were pallid sturgeon, and further identification (shovelnose sturgeon or hybrid [shovelnose sturgeon $\mathrm{x}$ pallid sturgeon]) was not performed. Two benthic otter trawls were used for fish collection. The first, termed the OT02, is a 4-mm mesh trawl ( $2.4 \mathrm{~m}$ wide with $0.76 \times 0.38 \mathrm{~m}$ otter doors) that is used to sample depths $<2 \mathrm{~m}$. The second, termed the OTO4, is a 4-mm mesh trawl (4.9 $\mathrm{m}$ wide with $0.91 \times 0.38 \mathrm{~m}$ otter doors) used to sample depths $>2 \mathrm{~m}$; however, sampling of depths $>5 \mathrm{~m}$ was usually avoided due to safety concerns (Gosch et al., 2017) and generally low catches of age-0 Scaphirhynchus sturgeon (Love, Phelps, Tripp, \& 
FIGURE 1 Map of 2014 and 2015 study reaches in the lower Missouri River with inset showing an example of the bend and trawl spatial scales

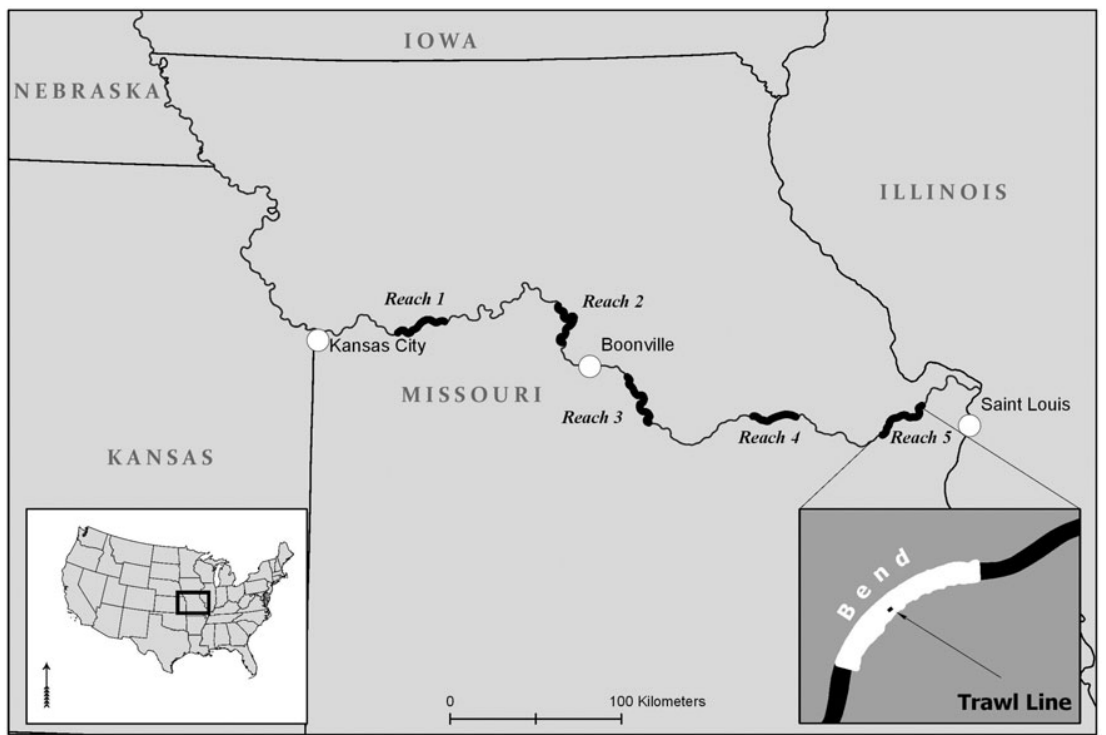

Herzog, 2017; Phelps et al., 2010). Depth was measured to the nearest $0.1 \mathrm{~m}$ at the beginning, middle, and end points of all trawls, and mean depth was used for analyses. Velocity measurements were collected for all trawls that yielded age-0 Scaphirhynchus sturgeon and at $25 \%$ of all noncapture trawls (Welker \& Drobish, 2016). Water velocity was measured near the bottom with a Marsh-McBirney flowmeter at the midpoint of each trawl. Trawl distances ranged in length from 75 to $300 \mathrm{~m}$ based upon Welker and Drobish (2016).

Following capture, individuals were measured to fork length (when a well-defined fork was present) or total length (excluding the caudal filament; Braaten et al., 2007) to the nearest mm. Each individual was then preserved in $100 \%$ ethanol and stored at approximately $0^{\circ} \mathrm{C}$. Up to 100 individuals per year (maximum of 20 per reach) from each of six length categories ( $\leq 20,21-40,41-60$, 61-80, 81-100, and 101-120 mm) were randomly selected for diet analysis and weighed to the nearest $0.0001 \mathrm{~g}$ at the conclusion of each field season (Civiello et al., 2018). To determine the weight of prey consumed, the lower esophagus and stomach of age-0 Scaphirhynchus sturgeon were removed in the laboratory, blotted dry, and weighed (mg). Gut contents were removed, and the stomach reweighed to estimate stomach content weight, which included unidentifiable material (Terry, 1976). Although ethanol preservation may reduce weight measurements (Garvey \& Chipps, 2012), all weighing for each individual was conducted postpreservation.

\section{2 | Habitat quantification}

We used a two-dimensional (2D) module of the USACE Hydrologic Engineering Center-River Analysis Software (HEC-RAS, version 5.0.1) to quantify the amount of recently defined foraging and foodproducing habitat in each reach. This model uses an Implicit Finite Volume algorithm to approximate the Shallow Water (SW) equations, which are simplifications of the three-dimensional fluid motion described by the Navier-Stokes equations. The Diffusive Wave Approximation of SW equation, the most simplified of the SW equations, was used in the model. It assumes that gravity and bottom friction are the dominant terms dictating river hydraulics while disregarding the unsteady, advection, and viscous terms (Hydrologic Engineering Center, 2016).

Model terrain was developed from two sources that included 2013 main channel bathymetry cross sections and 2014 low-water light detection and ranging data combined into a 3-m digital elevation model. For model generation, computation point spacing was $33 \mathrm{~m}$ or less in both the $x$ and $y$ directions, with a 6-m spacing, on average, near river structures and bank lines. For boundary conditions, the HEC-RAS models utilized data from available USGS gages, with the model's upstream and downstream boundaries generally set at the nearest gage. For reaches without gages near the upstream reach boundary (approximately $30 \mathrm{kms}$ ), we utilized gages within the reach and adjusted the time scale appropriately. Each 2D HEC-RAS model was calibrated using both daily flow and stage data for the entire sampling period in 2014 and 2015. Additionally, the models were calibrated to a 2014 low-water surface profile to ensure that the models accurately represented areas between gages. Models were calibrated to the available data by adjusting spatially varied Manning's $n$ values. Available Acoustic Doppler Current Profiler velocity data were used to validate the velocity output for each model (Appendix S1). We ran models for the entire study period using a 10-min time step.

To reduce the amount of data processing needed, daily habitat acreages were not calculated directly from model results. Instead, discharge versus habitat acreage rating curves (Figure 2) were constructed using model results for days having a daily discharge corresponding to the minimum, $10,25,50,75$, and 90 , and maximum percent exceedance within the May-October 2014-2015 study period. A geographic information system was used to identify areas that met depth and velocity ranges from model outputs for these days. A classification of rasters that met the hypothesized criteria for foodproducing $(<0.08 \mathrm{~m} / \mathrm{s})$ and foraging $(0.5-0.7 \mathrm{~m} / \mathrm{s}, 1-3 \mathrm{~m})$ habitats was used to the produced total acreage for these days. Daily habitat estimates (ha/ km) within each reach (Figure 3) were then calculated from daily discharge in conjunction with the habitat rating curves. To represent the area of a trawl, a $10 \mathrm{~m}$ buffer to each side of the line was 

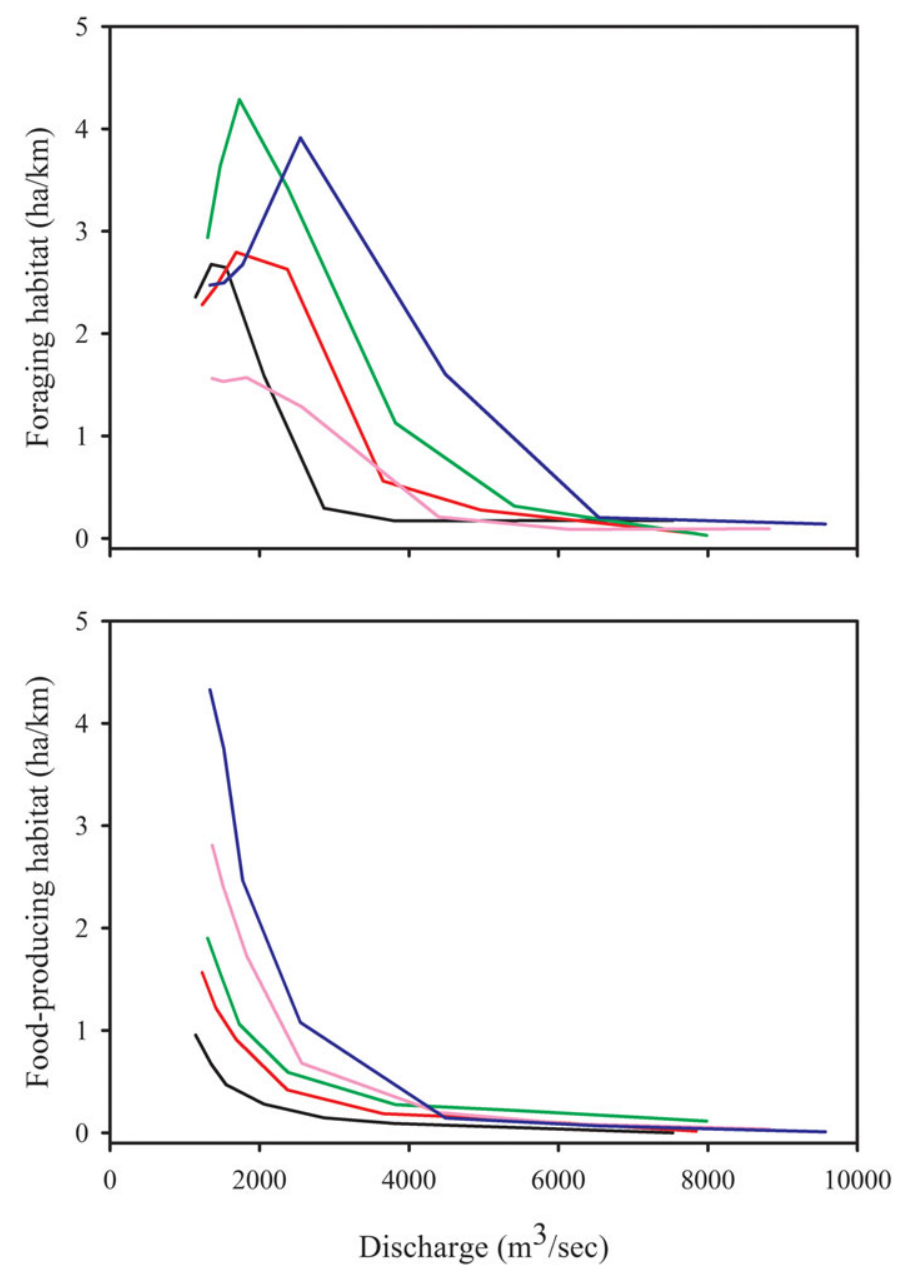

Reach 1 (Rkm 494-526) Reach 2 (Rkm 346-381)

Reach 3 (Rkm 253-290) Reach 4 (Rkm 151-177)
FIGURE 2 The amount of foraging and food-producing habitats under varying flow conditions for five reaches, by river kilometre, in the lower Missouri River [Colour figure can be viewed at wileyonlinelibrary.com] established, while maintaining the length of the trawl. We restricted habitat quantification to within-channel habitat; therefore, estimates of foraging and food-producing habitats were not quantified on the floodplain during out-of-bank flows. The number of days exceeding bankfull discharge, by year, for each reach are included in Table 1.

\section{3 | Data analysis}

We used trawls containing age-0 Scaphirhynchus sturgeon for all analyses except when evaluating depth and velocity at noncapture sites. To account for size-related differences among individuals, we standardized prey consumption by dividing the prey weight by the body weight multiplied by 100 (consumption percentage, hereinafter) for each individual (Chipps \& Garvey, 2007). For trawls that yielded multiple age-0 Scaphirhynchus sturgeon, the consumption percentage was averaged for all captures within that trawl. Using these values, we developed a consumption percentage matrix to determine if various combinations of depth and velocity led to increased prey consumption when controlling for body size. A consumption matrix was also constructed for each individual length category. To determine the effect of foraging habitat availability and year on the consumption percentage, we performed an aligned rank transformation (Higgins, Blair, \& Tashtoush, 1990; Wobbrock, Findlater, Gergle, \& Higgins, 2011) followed by a two-factor analysis of variance (Proc GLM; Kruskal-Wallis equivalent). The aligned rank transformation properly ranks the data to allow analysis of main and interaction effects in statistical models (Higgins et al., 1990; Wobbrock et al., 2011). When significant differences occurred, post hoc analyses with LSMEANS were interpreted at $a=0.05$.

To examine the possible influence of habitat quantity, we used linear regression to determine if prey consumption was correlated with the amount of foraging habitat at multiple spatial scales. To account for fish size, we regressed prey weight with body weight in order to calculate the studentized residuals for prey weight, which were used as the dependent variable in subsequent linear regression analyses at the reach, bend, and trawl spatial scales. Laboratory diet experiments demonstrated that age-0 pallid sturgeon (41-108 $\mathrm{mm}$ ) usually had low-gut fullness values after $24 \mathrm{hr}$ at water temperatures of 14,18 , and $24^{\circ} \mathrm{C}$ (Deslauriers, Rosburg, \& Chipps, 2017); thus, foraging habitat was calculated by averaging estimates from the day of capture and the previous day, which was then used as the independent variable. We used a Bonferroni correction $(0.05 / 3=0.017)$ to decrease the potential for a Type 1 error from multiple foraging habitat 

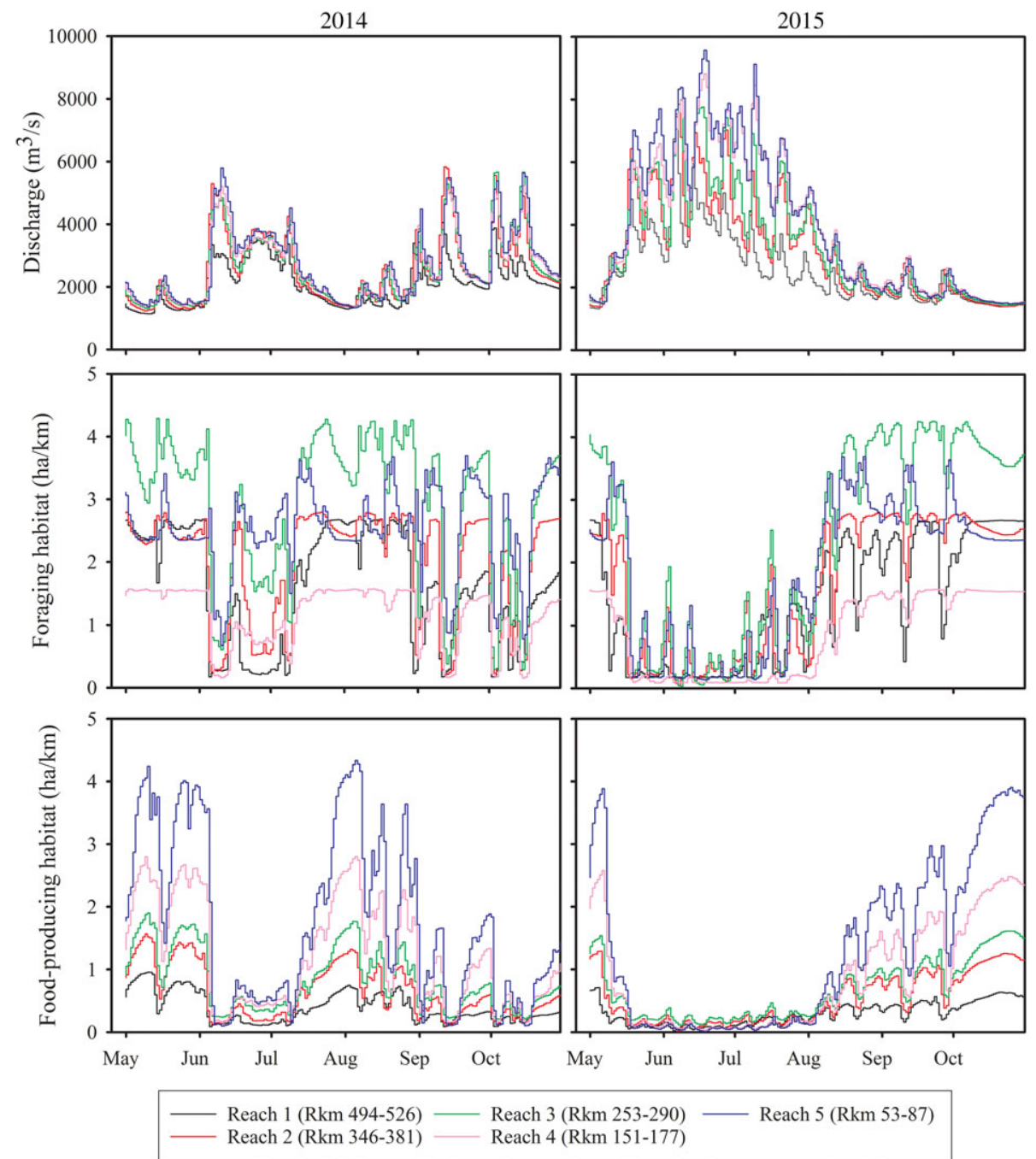

FIGURE 3 Discharge and daily estimates of foraging and food-producing habitats during 2014 and 2015 from five reaches, by river kilometre, in the lower Missouri River [Colour figure can be viewed at wileyonlinelibrary.com]

TABLE 1 The number of days for each modelled reach that experienced flows above bankfull levels during the study period (May-October during 2014 and 2015)

\begin{tabular}{lccc} 
Reach & Bankfull discharge $\left(\mathrm{m}^{3} / \mathrm{s}\right)$ & $\mathbf{2 0 1 4}$ (\# days) & $\mathbf{2 0 1 5}$ (\# days) \\
\hline 1 & $4,247.5$ & 0 & 18 \\
2 & $5,776.6$ & 1 & 15 \\
3 & $5,889.9$ & 0 & 24 \\
4 & $7,022.6$ & 0 & 21 \\
\hline 5 & $7,050.9$ & 0 & 25 \\
\hline
\end{tabular}

regressions. We conducted the same analysis to evaluate foodproducing habitat using the aforementioned 2-day average for each spatial scale; however, this type of habitat may be cumulative in nature and may involve lag time between the production of a prey item and consumption by age-0 Scaphirhynchus sturgeon. Therefore, we also evaluated the relationship between prey consumption and food-producing habitat by regressing the prey weight residuals to the daily average amount of food-producing habitat 10,20 , and
30 days prior to capture at the reach, bend, and trawl spatial scales. A Bonferroni correction was also used for food-producing regressions $(0.05 / 12=0.004)$.

\section{3 | RESULTS}

During this study, 365 trawls captured at least one age-0 Scaphirhynchus sturgeon, and only $21 \%$ of the trawls occurred in areas that met the proposed definition of age- 0 pallid sturgeon foraging habitat (0.5-0.7 m/s, 1-3 m; Figure 4). Of the noncapture trawls where velocity was measured, $16 \%$ (118 of 729 trawls) occurred in areas that met the proposed definition of age- 0 pallid sturgeon foraging habitat (Figure 4). As for prey consumed, the currently proposed foraging habitat criteria did not yield increased consumption percentage values, and there was no obvious pattern suggesting an optimal combination of depth and velocity for age-0 Scaphirhynchus sturgeon foraging (Table 2); similar results were observed for each length category (Appendix S2). When evaluating foraging habitat availability and year effects, the interaction was 


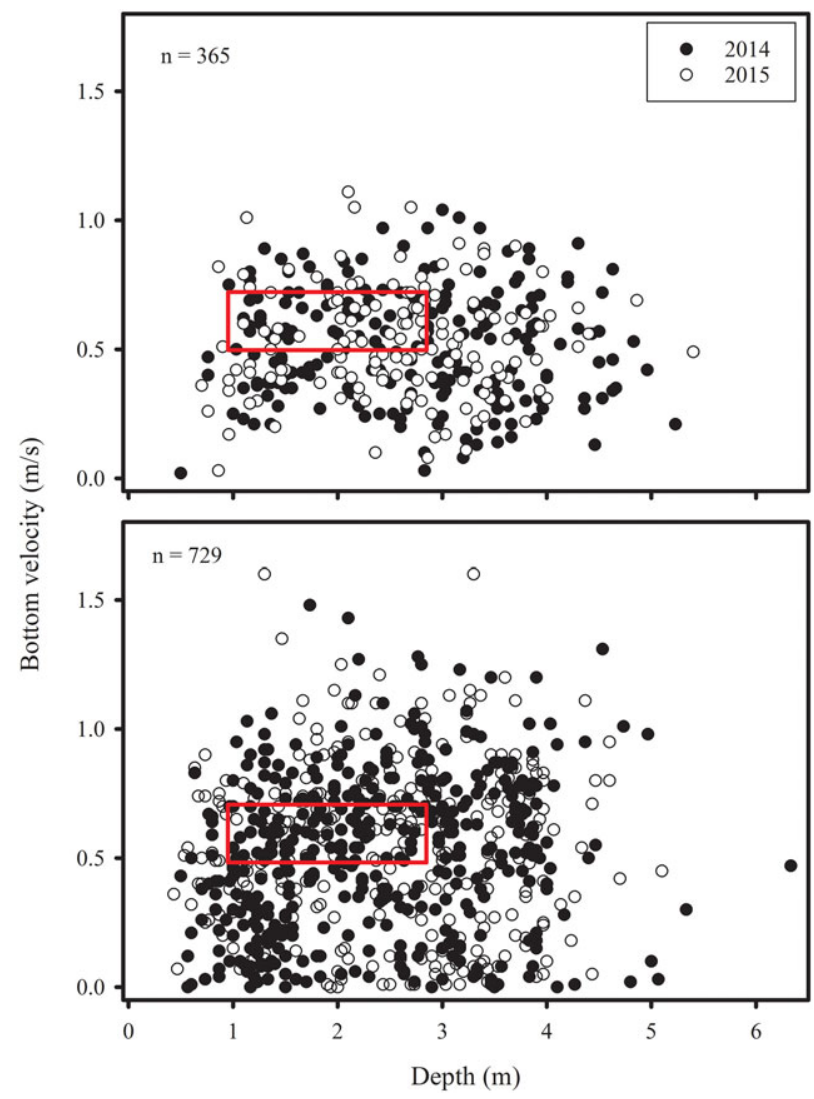

FIGURE 4 Bottom velocity $(\mathrm{m} / \mathrm{s})$ and depth $(\mathrm{m})$ at age-0 sturgeon capture (upper panel) and noncapture (lower panel) locations during 2014 and 2015. The red box encompasses the preliminary definition of foraging habitat proposed by Jacobson et al. (2016) [Colour figure can be viewed at wileyonlinelibrary.com] not significant $(d f=1, F=1.7, P=0.19)$. As for the main effects, year was significant $(d f=1, F=41.3, P<0.001$ ) with higher consumption percentages in 2015 than 2014. In contrast, consumption percentages from individuals captured within and outside the proposed age- 0 pallid sturgeon foraging habitat were not significantly different $(d f=1, F=0.1, P=0.82)$ (Figure 5).

Weight of prey consumed was significantly $\left(P<0.001, R^{2}=0.54\right.$, $d f=1$ ) and positively correlated with body weight (Figure 6 ). The prey weight residuals were not significantly $\left(P \geq 0.04, R^{2} \leq 0.01, d f=1\right)$ related to foraging habitat at the reach or trawl spatial scales (Figure 7). A significant relationship $\left(P<0.001, R^{2}=0.02, d f=1\right)$ did exist at the bend scale (Figure 7); however, little of the variation was explained by this regression model. As for food-producing habitat, we found a significant relationship $\left(P<0.001, R^{2}=0.05\right.$, df $=1$ ) between the prey weight residuals and the 2-day average of food producing habitat at the reach and bend spatial scales; however, little variation was explained by these regression models (Figure 7). In contrast, there was no significant relationship $\left(P=0.62, R^{2}<0.01, d f=1\right)$ at the trawl scale. At 10,20 , or 30 days precapture, we also found no significant $\left(P \geq 0.005, R^{2} \leq 0.02, d f=1\right)$ relationships, after the Bonferroni correction, with the prey weight residuals regardless of spatial scale (Figure 8).

\section{4 | DISCUSSION}

Occupancy alone may not suggest beneficial habitat (Dodrill et al., 2015), which was consistent with our foraging habitat assessment. Despite sampling a wide variety of depth and velocity combinations, we found that fewer than a quarter of trawls containing age-0

TABLE 2 Mean consumption percentage (prey weight/body weight $\times 100$ ), by trawl, from age-0 sturgeon captured in 2014 and 2015 at areas with specific depths $(\mathrm{m})$ and near bottom velocities $(\mathrm{m} / \mathrm{s})$

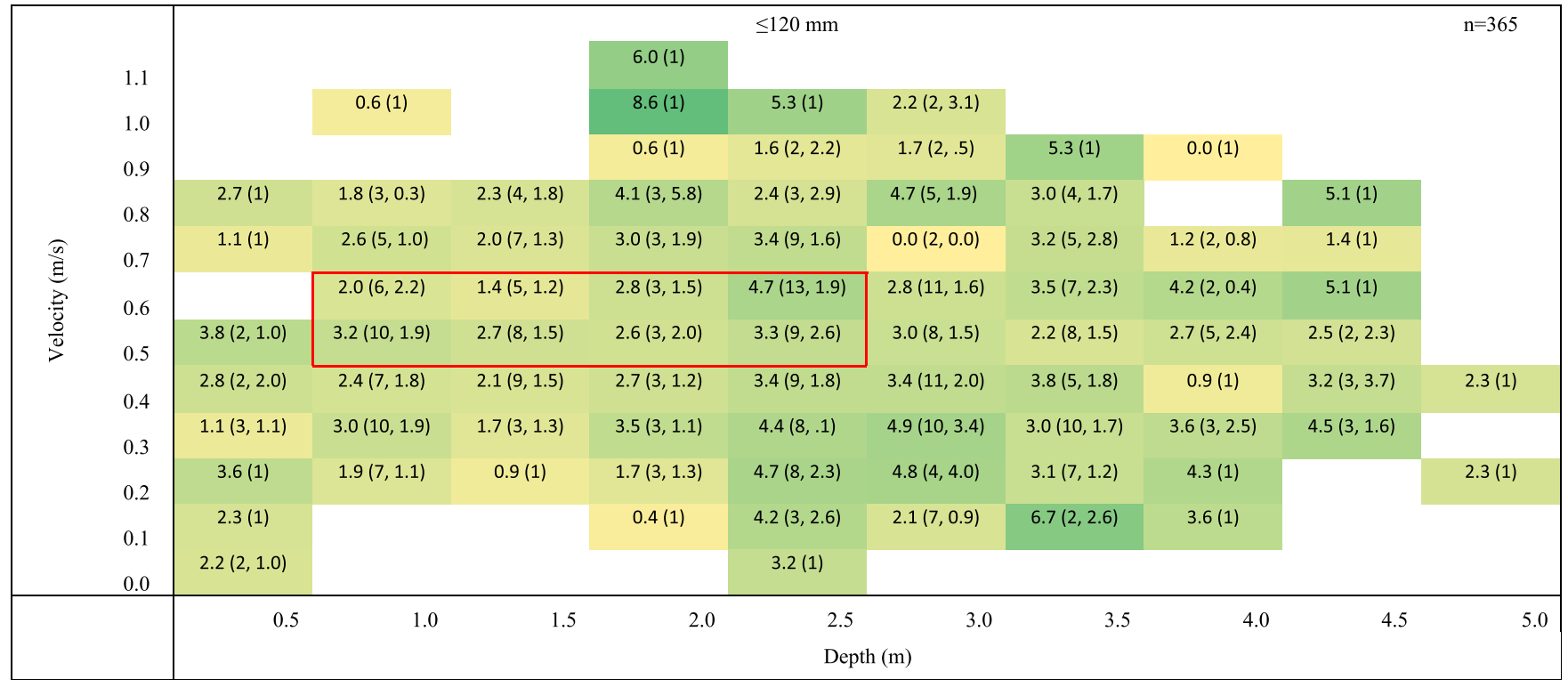


FIGURE 5 Box plots of the consumption percentage (prey weight/body weight $\times 100$ ) from age-0 sturgeon collected during 2014 and 2015 at proposed age- 0 sturgeon foraging and nonforaging habitats

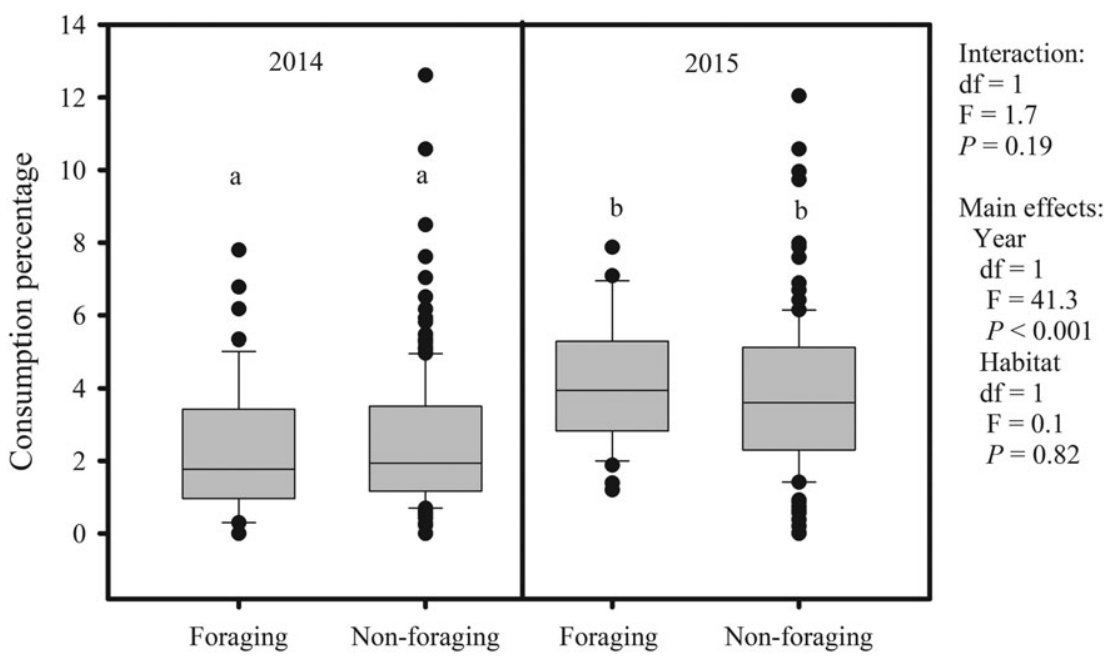

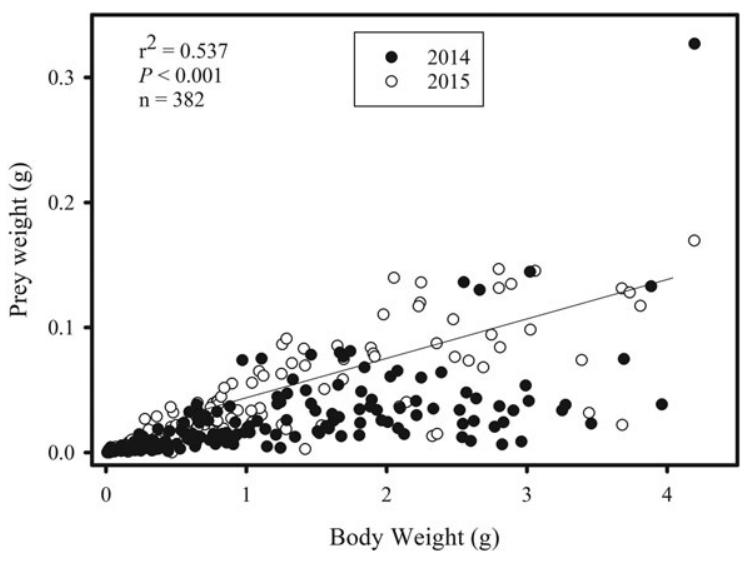

FIGURE 6 Regression plot of prey weight (g) and body weight (g) of age-0 sturgeon collected in 2014 (๑) and 2015 (०)

Scaphirhynchus sturgeon met the age-0 pallid sturgeon foraging habitat depth and velocity criteria proposed by Jacobson et al. (2016). Furthermore, individuals captured from areas meeting the proposed foraging habitat criteria did not have higher consumption percentages relative to individuals captured from areas not meeting the criteria. For example, only 1 of the highest 20 consumption percentage values observed during this study occurred within the currently defined foraging habitat. Because capture location was not necessarily where foraging occurred, we also evaluated prey consumption and foraging habitat availability at several larger spatial scales. Regardless of scale, however, the amount of proposed foraging habitat (Jacobson et al., 2016) had little influence on the amount of prey weight consumed by age- 0 Scaphirhynchus sturgeon. Additionally, uncertainty exists regarding the actual velocities used by age- 0 Scaphirhynchus sturgeon. For example, laboratory studies suggest that age-0 pallid sturgeon $<75 \mathrm{~mm}$ may not be able to hold position at velocities $\leq 0.3 \mathrm{~m} / \mathrm{s}$ (Kynard, Parker, Pugh, \& Parker, 2007; David Deslauriers, South Dakota State University, unpublished data); however, many individuals were captured from areas in the wild with measured velocities exceeding that threshold during this study and others (Gemeinhardt et al., 2016; Gosch et al., 2015; Gosch et al., 2017;
Ridenour et al., 2011). Furthermore, the vast majority of fish (>96\%) captured during this study also contained prey, suggesting these individuals were able to effectively forage regardless of the depths and velocities recorded. Most likely, near bed velocity measurements fail to accurately reflect the forces acting upon age-0 Scaphirhynchus sturgeon because the flow meter sensor is mounted to a lead sounding weight approximately $13-18 \mathrm{~cm}$ above the river bed. Additionally, the models are not capable of providing accurate estimates of velocities near the waterbed interface over a large spatial scale as HEC-RAS 2D models simply provide depth averaged velocities. Young and Scarnecchia (2005) reported the use of sand dunes by juvenile white sturgeon (Acipenser transmontanus) in the Koontenai River and hypothesized this was due to reduced, near-bed velocities associated with large river dunes. Similarly, a laboratory study demonstrated that age-0 pallid sturgeon (140-170 $\mathrm{mm}$ ) utilized sand dunes for energetic refugia (Porreca, Hintz, \& Garvey, 2017). Gosch et al. (2017) suggested that age-0 Scaphirhynchus sturgeon may not only need a specific range of depths and velocities but also acknowledged uncertainty regarding exact capture location during a trawl run. If local microhabitats, such as sand dunes, provide velocity refugia, this may explain how these benthic fishes are able to occupy and feed in a wide variety of depths and velocities. If true, defining habitat metrics would likely require a different approach, such as heavier reliance on understanding bed form for describing foraging habitat.

The amount of a priori defined food-producing habitat also appeared to have little effect on age-0 Scaphirhynchus sturgeon prey consumption; however, additional challenges exist, when linking food-producing habitat to prey consumption. The current hypothesis is that slow velocity areas $(<0.08 \mathrm{~m} / \mathrm{s})$ produce chironomids, and river currents transport these prey items to age-0 Scaphirhynchus sturgeon foraging areas (Jacobson et al., 2016). Age-0 Scaphirhynchus sturgeon in the LMOR mainly consume chironomids (Civiello et al., 2018; Gosch et al., 2016; Gosch et al., 2018), but the origin of these prey items (i.e., transported in the drift, produced in the benthos of foraging areas, or a combination of the two) is currently unknown. Additional research regarding the origin of chironomid prey available to Scaphirhynchus sturgeon would help identify and refine estimates of these essential 
Foraging habitat
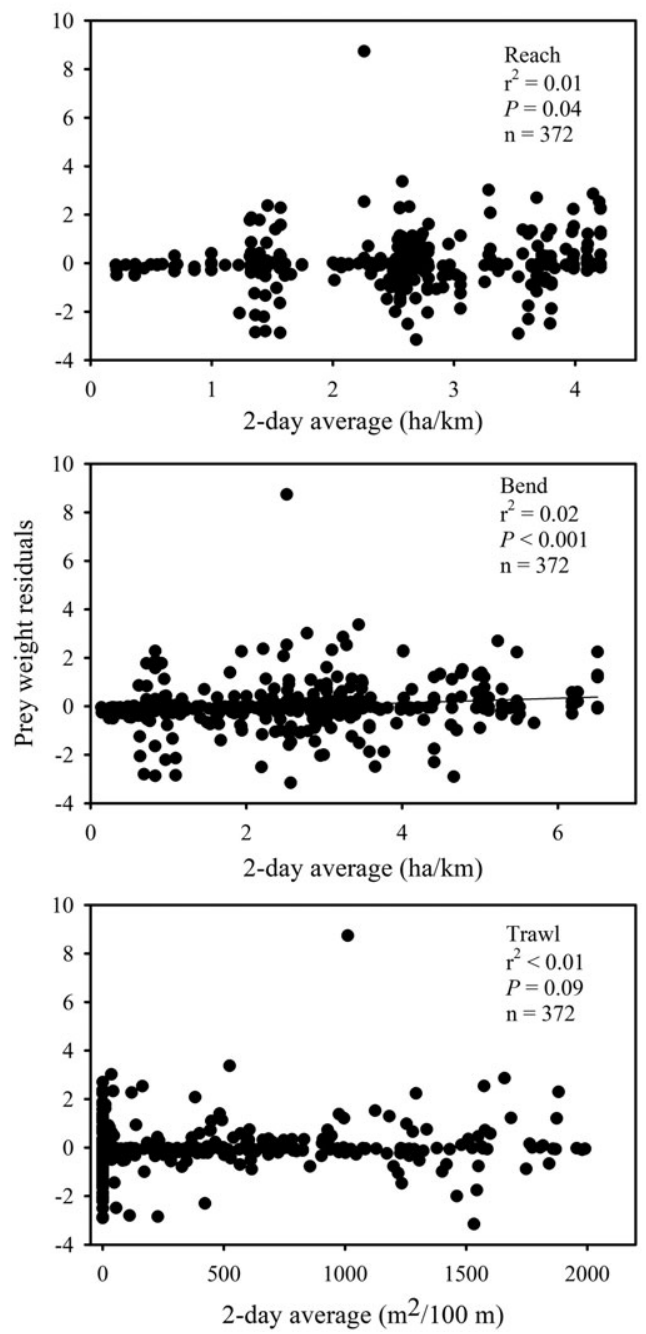

Food-producing habitat
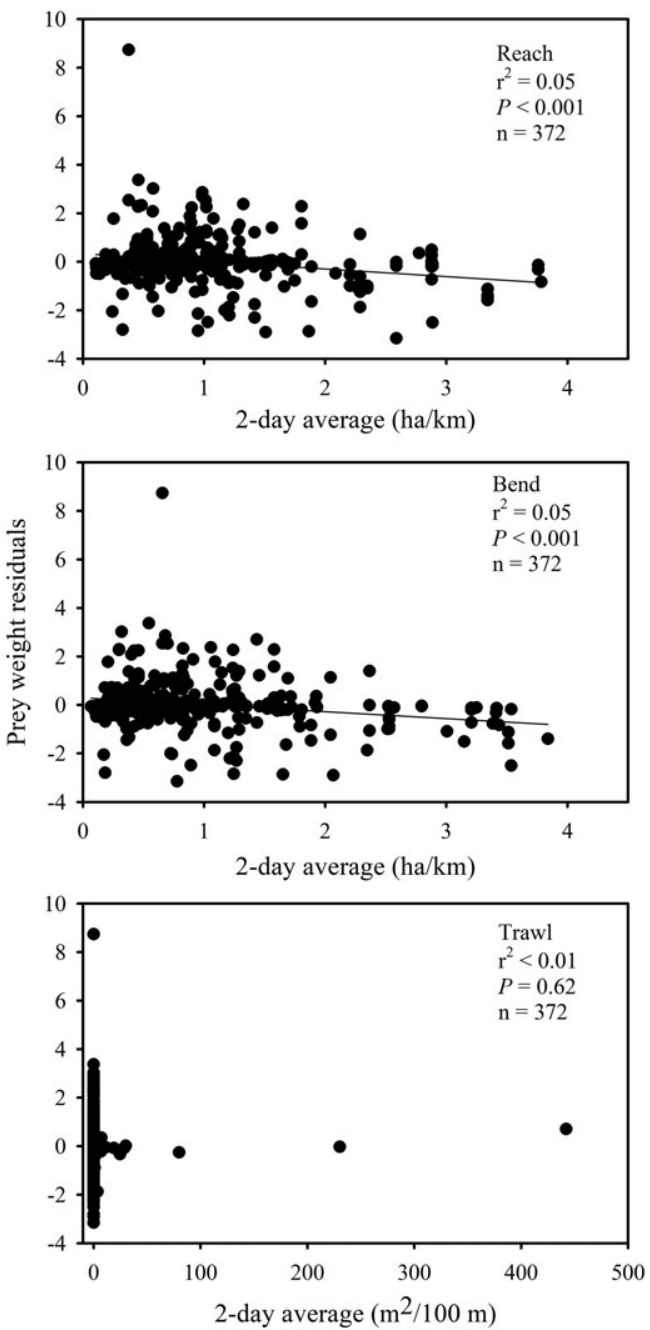

FIGURE 7 Regression plots of age-0 sturgeon prey weight residuals (calculated from Figure 6) and the average amount of foraging and foodproducing habitat from the day of capture and the previous day at three spatial scales (river reach, river bend, and trawl location) during 2014 and 2015

habitats. Another source of uncertainty involves the lag time between food production and consumption because transport of prey items may be flow-dependent. We attempted to address this issue using multiple temporal scales (10, 20, and 30 days); however, this approach may not have accurately accounted for the potential variability regarding food-producing habitats. Emigration and immigration is another potential concern; however, the lack of relationship at multiple spatial scales also suggests little spatial effect on the variables evaluated during this study.

Other, more complex, factors not evaluated as part of this study may influence prey consumption by age-0 Scaphirhynchus sturgeon. For example, mean discharge in the river was $17 \%$ to $54 \%$ greater during field collections in 2015 than in 2014, with concomitant increases in prey consumption (Civiello et al., 2018) even though within-channel food-producing habitat was greater in all reaches in 2014 than in 2015. A limitation of our study, however, was food producing, and foraging habitats were not quantified on adjacent floodplains during out-of-bank flows. Models produced by Erwin, Jacobson, and Elliott (2017) showed a significant increase in the amount of food-producing habitat on the lower Missouri River during out-of-bank flows, which occurred more frequently in 2015. Additionally, Harrison (2012) showed increased availability of nonburrowing prey within age-0 Scaphirhynchus sturgeon foraging habitat immediately following flow increases in the middle Mississippi River. Collectively, these results suggest differences in flow magnitude may affect annual production or availability of prey in the LMOR, although additional research would be necessary to evaluate this hypothesis. Regardless, we suggest that depth and velocity criteria alone may not influence prey consumption, which is likely a complex interaction of abiotic and biotic factors yet to be completely understood. A better understanding of the mechanisms that influence prey consumption is critical for river managers as the current results suggest efforts to restore habitat with specific depth and velocity criteria are unlikely to provide the hypothesized benefits to age-0 Scaphirhynchus sturgeon. As such, ongoing studies evaluating increased prey consumption with a broader suite of variables will allow for a multivariate approach to define those habitats necessary for successful age-0 sturgeon foraging. Furthermore, our 
10 Days

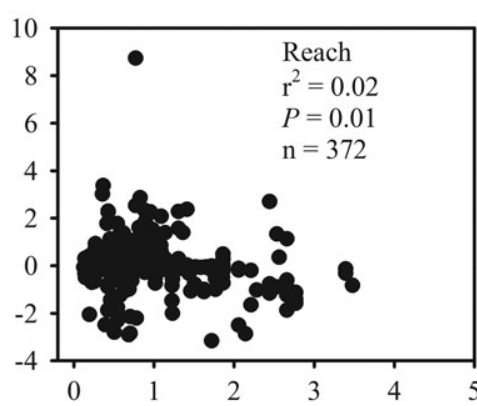

20 Days

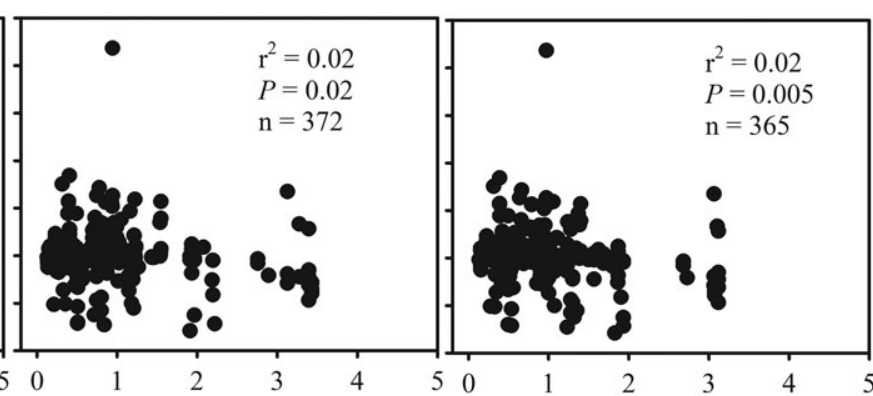

Average food-producing habitat (ha/ $/ \mathrm{km})$
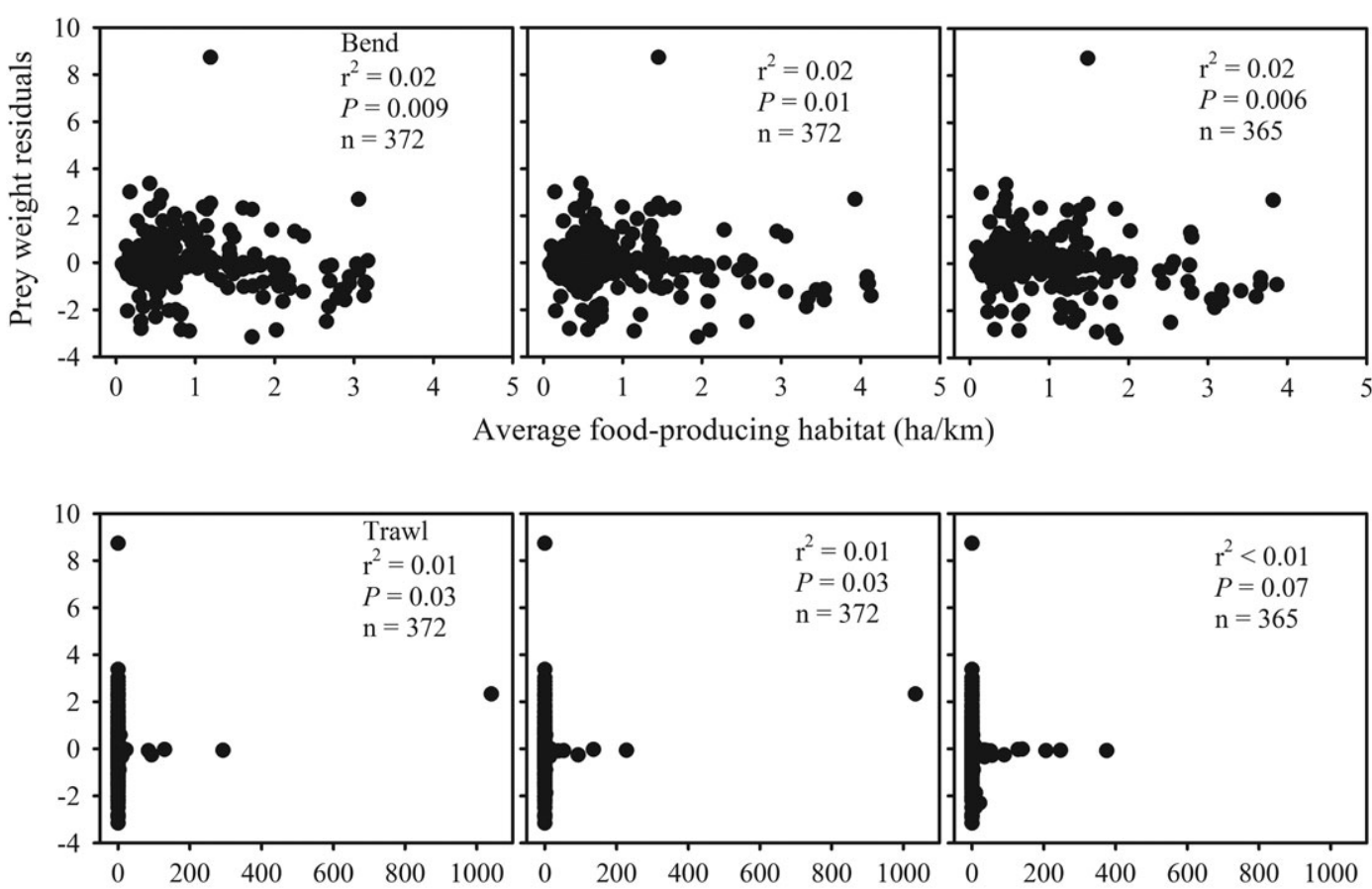

Average food-producing habitat $\left(\mathrm{m}^{2} / 100 \mathrm{~m}\right)$

FIGURE 8 Regression plots of age-0 sturgeon prey weight residuals (calculated from Figure 6) and the average amount of food-producing habitat from 10, 20, and 30 days before capture at three spatial scales (river reach, river bend, and trawl location) during 2014 and 2015

results suggest the current metrics used to evaluate restoration targets lack the biologically supported elements necessary to evaluate project success, which reinforces the need for adaptive management when implementing and evaluating management actions in the Missouri River (NRC, 2011; Doyle et al., 2011). Information from this study will be valuable as federal agencies and Missouri River stakeholders move into the adjustment period of the adaptive management cycle.

The current adaptive management plan (Fischenich et al., 2017) provides the framework for implementing and evaluating management actions identified in the effects analysis (Jacobson et al., 2016) in a step-wise approach, which allows for hypothesis testing prior to full implementation of a management action. For example, the annual restoration target for age- 0 pallid sturgeon habitat doubles after 6 years of habitat restoration, which will allow for physical and biological evaluations of project performance (and possible adjustments) prior to larger scale implementation. This differs from previous restoration actions on the lower Missouri River, which simply set a restoration target of 20,000 acres of shallow water habitat without testing of alternative, competing hypotheses. This new approach benefits both the pallid sturgeon and stakeholders by reducing the risk of implementing costly and ineffective actions for extended periods of time.

Adaptive management allows for managing uncertainty, and Jacobson et al. (2016) acknowledged that the proposed foraging and food-producing habitats were preliminary. Ideally, refined definitions would have been available for inclusion in the study of Jacobson et al. (2016); however, little information existed regarding potential relationships between prey consumption and habitat, such as depth and velocity. As such, Jacobson et al. (2016) suggested research to better understand the potential role these proposed habitats play during early life history. In response, we evaluated the relevance of the proposed foraging habitat definition finding little influence on age- 0 Scaphirhynchus sturgeon prey consumption, which also appeared true for depth and velocity in general. As such, we see little benefit to a revised foraging habitat definition based on depth and velocity criteria 
alone. Food-producing habitat, as proposed, also appears to have little influence on prey consumption regardless of the time period investigated (i.e., 10, 20, or 30 days before capture). If age-0 Scaphirhynchus sturgeon is a valid surrogate for age- 0 pallid sturgeon, these results suggest that the proposed depth and velocity criteria used to define age-0 pallid sturgeon foraging and food-producing habitat may not be useful in guiding habitat restoration projects, as actions focused on developing these conditions are unlikely to provide the hypothesized benefits. If food limitations are indeed a recruitment bottleneck for pallid sturgeon population growth, ongoing research evaluating other variables that may affect chironomid abundance and distribution (i.e., substrate composition, organic matter content, near-bed velocities, discharge, etc.) will provide a better understanding of foraging habitats that support age-0 Scaphirhynchus sturgeon. Nonetheless, the shovelnose sturgeon population in the LMOR appears stable (Steffensen, Stukel, \& Schuman, 2014) suggesting adequate recruitment to age-1, which indicates food-producing and foraging habitats regardless of how defined, occur in sufficient quantities to support age-0 shovelnose sturgeon survival (Civiello et al., 2018). Whether these findings apply to pallid sturgeon is still unknown, and other studies have highlighted the importance of better understanding potential surrogacy between shovelnose and pallid sturgeon during the first year of life (Gosch et al., 2017, 2018; Civiello et al., 2018). We also acknowledge that other posited elements of age-0 pallid sturgeon habitat, such as interception, may be important and deserving of future investigations in addition to other hypotheses identified by Fischenich et al. (2017; e.g., insufficient spawning habitat) to successfully guide management actions that result in pallid sturgeon population growth.

\section{ACKNOWLEDGEMENTS}

Funding was provided by the USACE, Kansas City and Omaha Districts and U.S. Geological Survey Cooperative Agreements G14AS0004 and G15 AC00323. We thank Marcus Miller, Justin Bounds, and USFWS-CFRO for assistance with data collection. We also thank Cecil Jennings for providing valuable comments on an earlier draft of this manuscript. Any use of trade, firm, or product names is for descriptive purposes only and does not imply endorsement by the U.S. Government. All product names and trademarks cited are the property of their respective owners. The findings of this report are not to be construed as an official Department of Army position unless so designated by other authorized documents. The Oklahoma Cooperative Fish and Wildlife Research Unit is supported by the Oklahoma Department of Wildlife Conservation, Oklahoma State University, U. S. Geological Survey, the Wildlife Management Institute, and the $U$. S. Fish and Wildlife Service. All necessary state and federal fish collection permits were acquired prior to study initiation. Fish were handled as described in the USFWS Biological Procedures and Protocols for Researchers and Managers Handling Pallid Sturgeon and the American Fisheries Society's Guidelines for the Use of Fishes in Research.

\section{ORCID}

Todd R. Gemeinhardt (iD https://orcid.org/0000-0002-1529-2531

Nathan J.C. Gosch (1D https://orcid.org/0000-0002-4993-642X
Anthony P. Civiello (D) https://orcid.org/0000-0002-7532-4961

James M. Long (D) https://orcid.org/0000-0002-8658-9949

\section{REFERENCES}

Braaten, P. J., Fuller, D. B., \& McClenning, N. D. (2007). Diet composition of larval and age-0 shovelnose sturgeon in the upper Missouri River. Journal of Applied Ichthyology, 23, 517-521. https://doi.org/10.1111/ j.1439-0426.2006.00822.x

Chipps, S. R., \& Garvey, J. E. (2007). Assessment of diets and feeding patterns. In C. S. Guy, \& M. L. Brown (Eds.), Analysis and interpretation of freshwater fisheries data (pp. 473-514). Maryland: American Fisheries Society.

Civiello, A. P., Gosch, N. J. C., Gemeinhardt, T. R., Miller, M. L., Bonneau, J. L., Chojnacki, K. A., \& Long, J. M. (2018). Reach-scale assessment of age-0 sturgeon diet and condition: implications for shallow-water habitat restoration. North American Journal of Fisheries Management, 38, 1324-1338. https://doi.org/10.1002/nafm.10236

Colombo, R. E., Garvey, J. E., \& Wills, P. S. (2007). A guide to the embryonic development of the shovelnose sturgeon (Scaphirhynchus platorynchus), reared at a constant temperature. Journal of Applied Ichthyology, 23, 402-410. https://doi.org/10.1111/j.149-0426.2007.00898.x. https:// doi.org/10.1111/j.1439-0426.2007.00898.x

Deslauriers, D., Rosburg, A. J., \& Chipps, S. R. (2017). Development of a foraging model framework to reliably estimate daily food consumption by young fishes. Canadian Journal of Fisheries and Aquatic Sciences, 74, 1668-1681. https://doi.org/10.1139/cjfas-2016-0331

Dodrill, M. J., Yackulic, C. B., Gerig, B., Pine, W. E. I. I. I., Korman, J., \& Finch, C. (2015). Do management actions to restore rare habitat benefit native fish conservation? Distribution of juvenile native fish among shoreline habitats of the Colorado River. River Research and Applications, 31, 1203-1217. https://doi.org/10.1002/rra.2842

Doyle M., Murphy D., Bartell S., Farmer A., Guy C., \& Palmer M. (2011). Missouri River Recovery Program Independent Science Advisory Panel-Final Report on Spring Pulses and Adaptive Management. Prepared for the U.S. Institute for Environmental Conflict Resolution and Missouri River Recovery Implementation Committee, 11-STRI-1482.

Eichelberger, J. S., Braaten, P. J., Fuller, D. B., Krampe, M. S., \& Heist, E. J. (2014). Novel single-nucleotide polymorphism markers confirm successful spawning of endangered pallid sturgeon in the upper Missouri River basin. Transactions of the American Fisheries Society, 143, 1373-1385. https://doi.org/10.1080/00028487.2014.935479

Erwin, S. O., Jacobson, R. B., \& Elliott, C. M. (2017). Quantifying habitat benefits of channel reconfigurations on a highly regulated river system, Lower Missouri River, USA. Ecological Engineering, 103, 59-75. https:// doi.org/10.1016/j.ecoleng.2017.03.004

Fischenich, J. C., Buenau, K. E., Bonneau, J. L., Fleming, C. A., Long, G., Marmorek, D. R., Nelitz, M. A., Murray, C. L., \& Schwartz, C. J. (2017). Missouri River Recovery Program Science and Adaptive Management Plan. ERDC TR 17-XX. U.S. Army Engineer Research and Development Center, Vicksburg, MS, June, 2018.599p.

Garvey, J. E., \& Chipps, S. R. (2012). Diets and energy flow. In A. V. Zale, D. L. Parrish, \& T. M. Sutton (Eds.), Fisheries techniques (third ed.) (pp. 733-779). Bethesda, MD, USA: American Fisheries Society.

Gemeinhardt, T. R., Gosch, N. J. C., Morris, D. M., Miller, M. L., Welker, T. L., \& Bonneau, J. L. (2016). Is shallow water a suitable surrogate for assessing efforts to address pallid sturgeon population declines? River Research and Applications, 32, 734-743. https://doi.org/10.1002/ rra.2889

Gosch, N. J. C., Civiello, A. P., Gemeinhardt, T. R., Bonneau, J. L., \& Long, J. M. (2018). Are shovelnose sturgeon a valid diet surrogate for endangered pallid sturgeon during the first year of life? Journal of Applied Ichthyology, 34, 39-41. https://doi.org/10.1111/jai.13512

Gosch, N. J. C., Gemeinhardt, T. R., Bouska, W. W., Miller, M. L., Brown, T. L., \& Bonneau, J. L. (2017). Age-0 sturgeon and shallow water: A localand reach-scale assessment. River Research and Applications, 33, 1452-1462. https://doi.org/. https://doi.org/10.1002/rra.3195 
Gosch, N. J. C., Miller, M. L., Gemeinhardt, T. R., Sampson, S. J., \& Bonneau, J. L. (2015). Age-0 sturgeon accessibility to constructed and modified chutes in the lower Missouri River. North American Journal of Fisheries Management, 35, 75-85. https://doi.org/10.1080/02755947.2014.975300

Gosch, N. J. C., Miller, M. L., Gemeinhardt, T. R., Starks, T. A., Civiello, A. P., Long, J. M., \& Bonneau, J. L. (2016). Age-0 shovelnose sturgeon prey consumption in the lower Missouri River. River Research and Applications, 32, 1819-1823. https://doi.org/10.1002/rra.3003

Hall, J., Steffensen, K. M., Eder, G., Ames, B., Winders, C., \& Whiteman, K. (2016). Characterizing best achievable habitat conditions for Missouri River side-channel habitat restoration projects. Final report prepared for the U.S. Army Corps of Engineers - Missouri River Recovery Program. $55 \mathrm{p}$.

Harrison, A. B. (2012). The diets of larval and juvenile pallid sturgeon and shovelnose sturgeon (Scaphirhynchus spp.) in the lower Mississippi River. Master's Thesis, Clemson University.

Harrison, A. B., Slack, W. T., \& Killgore, J. K. (2014). Feeding habitats of age-0 river sturgeon Scaphirhynchus spp. in the lower Mississippi River. American Midland Naturalist, 171, 54-67. https://doi.org/ 10.1674/0003-0031-171.1.54

Higgins, J. J., Blair, R. C., \& Tashtoush, S. (1990). The aligned rank transform procedure. Annual Conference on Applied Statistics in Agriculture. http://newprairiepress.org/agstatconference/1990/proceedings/18, DOI: https://doi.org/10.4148/2475-7772.1443.

Hydrologic Engineering Center (2016). HEC-RAS River analysis system. Davis CA: U.S. Army Corps of Engineers.

Jacobson, R. B., Annis, M. L., Colvin, M. E., James, D. A., Welker, T. L., \& Parsley, M. J. (2016). Missouri River Scaphirhynchus albus (pallid sturgeon) effects analysis-Integrative report 2016: U.S. Geological Survey Scientific Investigations Report, 2016-5064, 154.

Kynard, B., Parker, E., Pugh, D., \& Parker, T. (2007). Use of laboratory studies to develop a dispersal model for Missouri River pallid sturgeon early life intervals. Journal of Applied Ichthyology, 23, 365-374. https://doi. org/10.1111/j.1439-0426.2007.00908.x

Love, S. A., Phelps, Q. E., Tripp, S. J., \& Herzog, D. P. (2017). The importance of shallow-low velocity habitats to juvenile fish in the middle Mississippi River. River Research and Applications, 33, 321-327. https://doi.org/10.1002/rra.3075

Murphy, D. D., \& Weiland, P. S. (2011). The route to best science in implementation of the endangered species act's consultation mandate: The benefits of structured effects analysis. Environmental Management, 47, 161-172. https://doi.org/10.1007/s00267-010-9597-9

National Research Council (NRC) (2011). Missouri River planning-recognizing and incorporating sediment management (p. 152). Washington D.C.: National Academies Press.

Olson, M. (2009). Clarification of the definition of shallow-water habitatLetter to the U.S. Army Corps of Engineers: U.S. Fish and Wildlife Service.

Phelps, Q. E., Tripp, S. J., Garvey, J. E., Herzog, D. P., Ostendorf, D. E., Ridings, J. W., \& Hrabik, R. A. (2010). Habitat use during early life history infers recovery needs for shovelnose sturgeon and pallid sturgeon in the middle Mississippi River. Transactions of the American Fisheries Society, 139, 1060-1068. https://doi.org/10.1577/T09-199.1

Porreca, A. P., Hintz, W. D., \& Garvey, J. E. (2017). Do alluvial sand dunes create energetic refugia for benthic fishes? An experimental test with the endangered pallid sturgeon. River Research and Applications, 33, 690-696. https://doi.org/10.1002/rra.3132

Ridenour, C. J., Doyle, W. J., \& Hill, T. D. (2011). Habitats of age-0 sturgeon in the lower Missouri River. Transactions of the American Fisheries Society, 140, 1351-1358. https://doi.org/10.1080/00028487.2011.620493

Runge, M. C. (2011). An introduction to adaptive management for threatened and endangered species. Journal of Fish and Wildlife Management, 2, 220-233. https://doi.org/10.3996/082011-JFWM-045
Schrey, A. W., Sloss, B. L., Sheehan, R. J., Heidinger, R. C., \& Heist, E. J. (2007). Genetic discrimination of middle Mississippi River Scaphirhynchus sturgeon into pallid, shovelnose, and putative hybrids with multiple microsatellite loci. Conservation Genetics, 8, 683-693. https://doi.org/10.1007/s10592-006-9215-9

Sechler, D. R., Phelps, Q. E., Tripp, S. J., \& Garvey, J. E. (2012). Habitat for age- 0 shovelnose sturgeon and pallid sturgeon in a large river: Interactions among abiotic factors, food, and energy intake. North American Journal of Fisheries Management, 32, 24-31. https://doi.org/10.1080/ 02755947.2012.655848

Sechler, D. R., Phelps, Q. E., Tripp, S. J., Garvey, J. E., Herzog, D. P., Ostendorf, D. E., ... Hrabik, R. A. (2013). Effects of river stage height and water temperature on diet composition of year-0 sturgeon (Scaphirhynchus spp.): a multi-year study. Journal of Applied Ichthyology, 29, 44-50. https://doi.org/10.1111/jai.12047

Steffensen, K. D., Stukel, S., \& Shuman, D. A. (2014). The status of fishes in the Missouri River, Nebraska: shovelnose sturgeon (Scaphirhynchus platorynchus). Transaction of the Nebraska Academy of Sciences and Affiliated Societies, 34, 16-26.

Terry, C. (1976). Stomach analysis methodology: Still lots of questions. In Proceedings of the 1st Pacific northwest technical workshop on fish food habitats. Seattle: Washington Sea Grant Publication.

U.S Fish and Wildlife Service (USFWS) (2018). Biological opinion on the operation of the Missouri River main stem reservoir system, operation and maintenance of the Missouri River bank stabilization and navigation project and operation of the Kansas River reservoir system. USFWS: Mountain Prairie Region. Denver, CO.

U.S. Fish and Wildlife Service (USFWS) (2000). Biological opinion of the operation of the Missouri River main stem reservoir system, operation and maintenance of the Missouri River bank stabilization and navigation project and operation of the Kansas River reservoir system. USFWS: Washington D.C.

U.S. Fish and Wildlife Service (USFWS) (2003). Amendment to the 2000 biological opinion of the operation of the Missouri River main stem reservoir system, operation and maintenance of the Missouri River bank stabilization and navigation project and operation of the Kansas River reservoir system. USFWS: Washington D.C.

Welker, T. L., \& Drobish, M. R. (Eds.) (2016). Missouri River standard operating procedures for fish sampling and data collection, volume 1.8. Omaha District, Yankton, SD: U.S. Army Corps of Engineers.

Wobbrock, J. O., Findlater, L., Gergle, D., \& Higgins J. J. (2011). The aligned rank transform for nonparametric factorial analyses using only ANOVA procedures. Proceedings of the ACM Conference on Human Factors in Computing Systems. ACM Press, New York, Vancouver, British Columbia.

Young, W. T., \& Scarnecchia, D. L. (2005). Habitat use of juvenile white sturgeon in the Kootenai River, Idaho and British Columbia. Hydrobiologia, 537, 265-271. https://doi.org/10.1007/s10750-004-1639-y

\section{SUPPORTING INFORMATION}

Additional supporting information may be found online in the Supporting Information section at the end of the article.

How to cite this article: Gemeinhardt TR, Gosch NJC, Civiello $\mathrm{AP}$, et al. The influence of depth and velocity on age-0 Scaphirhynchus sturgeon prey consumption: Implications for aquatic habitat restoration. River Res Applic. 2019;35:205-215. https://doi.org/10.1002/rra.3395 